\title{
Novel high glass temperature sugar-based epoxy resins: Characterization and comparison to mineral oil-based aliphatic and aromatic resins
}

\author{
P. Niedermann*, G. Szebényi, A. Toldy \\ Department of Polymer Engineering, Faculty of Mechanical Engineering, Budapest University of Technology and \\ Economics, Mủegyetem rkp. 3., H-1111 Budapest, Hungary
}

Received 19 June 2014; accepted in revised form 17 August 2014

\begin{abstract}
Curing and rheological behaviour, glass transition temperature, mechanical and thermal properties of two newly synthesized glucopyranoside- (GPTE) and glucofuranoside- (GFTE) based renewable epoxy resin (EP) components were investigated and compared to aromatic and aliphatic EPs. The glucose-based EPs can be successfully cured with amine and anhydride type curing agents, their gel times are suitable for processing and can be well-adopted to the needs of the common composite preparation methods. GPTE showed the highest glass transition temperature $\left(T_{\mathrm{g}}\right)$ among all investigated resins, followed by GFTE and DGEBA. Below the $T_{\mathrm{g}}$ there was no significant difference between the storage modulus values of the EP systems. The glucose-based EPs had lower tensile and bending strength, but their tensile modulus values are not significantly different from the mineral oil based EPs. The thermal stability of the synthesized GPTE and GFTE is between DGEBA and the aliphatic resins. In applications where bending stresses are dominant over the tensile ones, and outstanding $T_{\mathrm{g}}$ is required, these glucose-based resins offer a feasible renewable option.
\end{abstract}

Keywords: biopolymers, high glass temperature, thermal properties, mechanical properties, aircraft applications

\section{Introduction}

In the recent years intensive research work has been focused on the partial or full replacement of the mineral oil based epoxy resin (EP) components by renewable ones in several industrial segments in order to reduce their dependence on petrochemicals. The synthesis of bio-based EPs is feasible from different natural materials such as wood biomass [1], industrial lignin [2] and starch [3]. One of the most common methods to prepare bio-based EPs is the epoxidation of different vegetable oils, which are basically fatty acid esters of glycerol [4-8]. For the functionalization of plant oils (epoxidation of the unsaturated fatty acid chains double bonds) many chemical solutions were worked out $[9,10]$. Basically there are four methods: epoxidation with percarboxylic acids; with inorganic or organic peroxides; with halohydrines or with molecular oxygen [11]. Many investigations deal with the mechanical properties of the neat epoxidized plant oils (EPOs) and mixed EPO/ petrol oil based EP (mostly DGEBA - diglycidyl ether of bisphenol A) systems [12-26]. According to the literature in these hybrid EP systems usually phase separation was observed [12, 20, 21]. In all cases the glass transition temperature $\left(T_{\mathrm{g}}\right)$, thermal, tensile and bending properties decreased by increasing EPO-content, so the EPOs behaved basically as plasticizers. On the other hand, the impact strength of petrol oil based EPs increased at 20 mass\% EPOcontent [13], and the epoxidized triglycerides were tougher than DGEBA [14]. Besides the mechanical properties, the curing process also was investigated

\footnotetext{
${ }^{*}$ Corresponding author, e-mail: niedermann@pt.bme.hu (C) BME-PT
} 
with many types of curing agents [19, 22]. With synthetic aliphatic EP components, the $T_{\mathrm{g}}$ values increased with increasing ESO-content, followed by a slight decrease in mechanical properties [26]. Based on the literature, the EPOs can be applied as renewable sourced polymer matrices in fiber reinforced polymer composites, however high-tech applications as aeronautical require much higher $T_{\mathrm{g}}$ and better mechanical properties.

Sugar is a renewable resource that has the potential to replace mineral oil in the synthesis of EPs, furthermore due to its large oversupply in the recent decades its application as base material in polymer synthesis does not compete with the food industry. Sugar based EP components can be synthesized by replacing the hydroxyl groups of sugar structured molecules as cardanol [27-29], sucrose [30, 31], maltitol, sorbitol [32] and isosorbide [33-36] with oxirane functions. With the mixture of a novel synthesized cardanol based novolac-type phenolic resins and polybutadiene liquid rubber (CTPB) tensile strength improvement and higher thermal stability could be achieved with increasing CTPB-content. [27]. With poly(butadiene-co-acrylonitrile) (CTBN) the tensile strength decreased, but with 15 mass\% CTBN-content, the impact strength increased [28, 29]. Cured epoxy allyl sucrose (EAS) and epoxy crotyl sucrose (ECS) were compared to DGEBA by Pan et al. [30]. The EAS had lower and the ECS had higher tensile strength and modulus than the DGEBA. From sucrose based starting materials cured epoxidized sucrose ester of fatty acids can be formed, which has higher tensile strength and modulus than the commercially available epoxidized soybean oil (ESO) [31]. Shibata et al. [32] achieved tensile strength improvement with 10 mass $\%$ microfibrillated cellulose fiber reinforce- ment in glycerol polyglycidyl ether (GPE) and sorbitol polyglycidyl ether (SPE) matrix materials. Isosorbide is also an alternative source to synthesize renewable sourced epoxy components [33-35]. Chrisanthos et al. [36] synthesized two hygroscopic isosorbide based EP components. The mechanical properties of renewable sourced cured EP components were compared to DGEBA. They reached higher rubbery modulus above $T_{\mathrm{g}}$, but the $T_{\mathrm{g}}$ values were lower than in the case of DGEBA.

In this work curing and rheological behaviour, glass transition temperature, mechanical and thermal properties of two novel glucose-based EP components were investigated. These results were not only compared to the conventional, widely investigated aromatic diglycidyl ether of bisphenol A (DGEBA) resin, but also to a glycerol- (GER) and a pentaerythritol-based (PER) aliphatic resin, which are currently synthesized on mineral oil base, however they can be potentially synthesized from renewable sources: glycerol is available in large quantities from natural fatty acids, while pentaerythritol can be produced from bio-based methanol as well. The expected outcome of this study was to determine the potential application areas, where these newly developed glucose-based EP components are capable of replacing the mineral oil based commodity resins.

\section{Experimental}

\subsection{Materials}

As renewable epoxy resin components two glucosebased components, synthesized previously by the research group of the authors [37], were used: a solid glucopyranoside based trifunctional epoxy resin component (GPTE) and a liquid glucofuranoside based trifunctional epoxy resin component (GFTE).
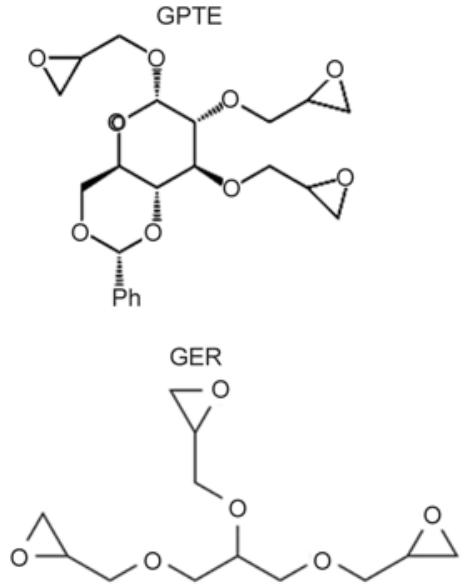
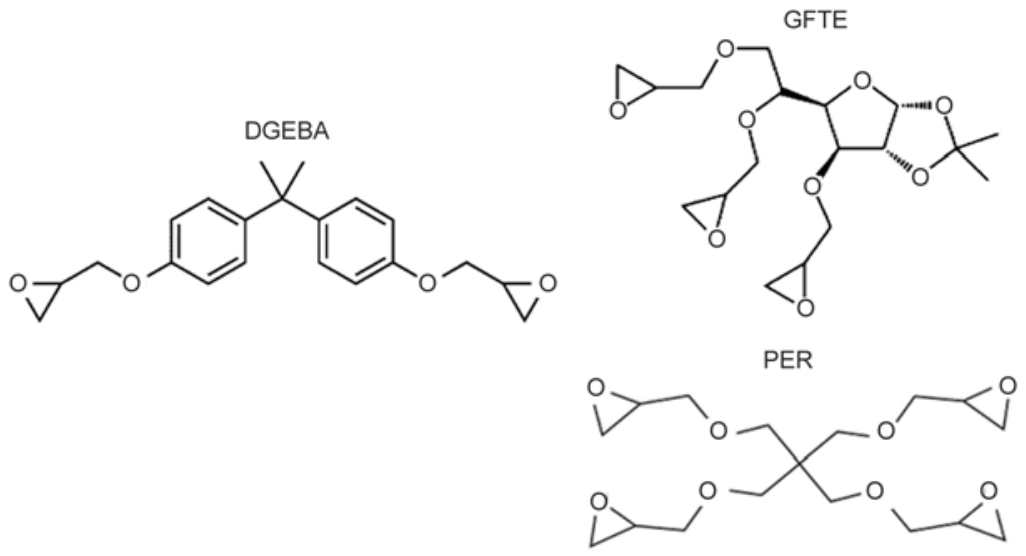

Figure 1. Chemical structure of the applied EP components 
Table 1. Characteristics of the applied EP components

\begin{tabular}{|c|c|c|c|c|c|c|}
\hline Abbreviation & Main component & Supplier & $\begin{array}{l}\text { Trade } \\
\text { name }\end{array}$ & \begin{tabular}{|c|} 
Phase / Structure \\
/ Viscosity [Pa $\cdot$ s] \\
$\left(\right.$ at $\left.25^{\circ} \mathrm{C}\right)$ \\
{$[-]$}
\end{tabular} & $\begin{array}{c}\text { Molecular } \\
\text { weight } \\
\text { [g/mol] }\end{array}$ & $\begin{array}{c}\text { Epoxy } \\
\text { equivalent } \\
\text { weight }(\mathrm{EEW}) \\
{[\mathrm{g} / \mathrm{eq}]}\end{array}$ \\
\hline GPTE & $\begin{array}{l}\left(2^{\prime}, 3^{\prime} \text {-epoxypropyl)-2,3-di-O- }\right. \\
\left(2^{\prime}, 3^{\prime} \text {-epoxypropyl)-4,6-O-ben- }\right. \\
\text { zylidene- } \alpha \text {-D-glucopyranoside }\end{array}$ & $\begin{array}{l}\text { synthesized at Budapest } \\
\text { University of Technology } \\
\text { and Economics [37] }\end{array}$ & - & $\begin{array}{c}\text { Solid / } \\
\text { Cycloaliphatic }\end{array}$ & 436 & 160 \\
\hline GFTE & $\begin{array}{l}\text { 3,5,6-tri-O-(2,3-epoxypropyl)- } \\
\text { 1,2-O-isopropylidene- } \alpha \text {-D-glu- } \\
\text { cofuranose }\end{array}$ & $\begin{array}{l}\text { synthesized at Budapest } \\
\text { University of Technology } \\
\text { and Economics [37] }\end{array}$ & - & $\begin{array}{c}\text { Liquid / } \\
\text { Cycloaliphatic / } \\
3.76\end{array}$ & 388 & 160 \\
\hline DGEBA & $\begin{array}{l}\text { Diglycidyl ether of bisphe- } \\
\text { nol A }\end{array}$ & $\begin{array}{l}\text { IPOX Chemicals Ltd. } \\
\text { (Budapest, Hungary) }\end{array}$ & ER1010 & $\begin{array}{c}\text { Liquid / Aromatic / } \\
10-14\end{array}$ & 340 & 188 \\
\hline GER & Triglycidyl ether of glycerol & $\begin{array}{l}\text { IPOX Chemicals Ltd. } \\
\text { (Budapest, Hungary) }\end{array}$ & MR3012 & $\begin{array}{c}\text { Liquid / Aliphatic / } \\
0.9\end{array}$ & 274 & 144 \\
\hline PER & $\begin{array}{l}\text { Tetraglycidyl ether of pen- } \\
\text { taerythritol }\end{array}$ & $\begin{array}{l}\text { IPOX Chemicals Ltd. } \\
\text { (Budapest, Hungary) }\end{array}$ & MR3016 & $\begin{array}{c}\text { Liquid / Aliphatic / } \\
0.24\end{array}$ & 360 & 168 \\
\hline
\end{tabular}

As conventional mineral oil based resins the bifunctional aromatic bisphenol-A based DGEBA and two aliphatic components, the trifunctional glycerolbased GER and the tetrafunctional pentaerythritolbased PER were used. The chemical structure of these components can be seen in Figure 1, while their characteristics are listed in Table 1.

As hardener two types of curing agents were applied: an amine and an anhydride with accelerator. The amine curing agent was diethylene-toluene-tetramine with $45 \mathrm{~g} /$ eq hydrogen equivalent (DETDA80 DETDA) by Lonza (Basel, Switzerland). The anhydride was methyl-tetrahydrophtalic-anhydride with minimal tetrahydrophtalic anhydride content (Aradur 917 - AR917) with 1-methylimidazole (DY070) accelerator by Huntsman Advanced Materials (Basel, Switzerland). The equivalent mass of the anhydride type curing agent, calculated form its molecular mass, was $160 \mathrm{~g} / \mathrm{eq}$. The accelerator was applied in 2 mass\% related to the mass of the epoxy resin component. During the composite preparation in all cases stoichiometric ratio of EP component and hardener was used. The macro scaled specimens for the mechanical investigations were made by resin moulding with a vertical moulding tool. The curing procedure, determined on the basis of DSC and gel time tests, consisted of the following isothermal heat steps: $1 \mathrm{~h}$ at $100^{\circ} \mathrm{C}, 1 \mathrm{~h}$ at $150^{\circ} \mathrm{C}$ and $2 \mathrm{~h}$ at $175^{\circ} \mathrm{C}$ in the case of DETDA, and $2 \mathrm{~h}$ at $100^{\circ} \mathrm{C}$ and $2 \mathrm{~h}$ and $140^{\circ} \mathrm{C}$ with AR917.

\subsection{Methods}

\subsubsection{Differential scanning calorimetry (DSC)}

The DSC tests were carried out with Q2000 device of TA Instruments (New Castle, DE, USA) in $50 \mathrm{~mL} / \mathrm{min}$ nitrogen flow. Tzero type aluminium pans were used, the sample mass was $5-10 \mathrm{mg}$. For the investigation of the curing process of the samples the applied three-step temperature program consisted of heat/cool/heat cycles: after a linear ramp from $25-250^{\circ} \mathrm{C}$ with $5^{\circ} \mathrm{C} / \mathrm{min}$ heat rate (first cycle), the sample was cooled down to $0^{\circ} \mathrm{C}$ with $50^{\circ} \mathrm{C} / \mathrm{min}$ cooling rate, followed by a second linear heating ramp from $0-250^{\circ} \mathrm{C}$ with $5^{\circ} \mathrm{C} / \mathrm{min}$ heating rate $(\mathrm{sec}-$ ond cycle) to ensure the proper conversion. The glass transition temperature $\left(T_{\mathrm{g}}\right)$ values were determined from the second heating scan and were defined as the inflection point of the transition curve. After the heat/cool/heat cycle isothermal measurements were carried out as well to determine proper curing circumstances for macro-scaled specimen preparation. After carrying out the specific curing cycles on macro-scaled samples, determined on the basis of DSC results and gel time, the conversion of the specimens was checked by applying a linear heating ramp from $0-250^{\circ} \mathrm{C}$ with $5^{\circ} \mathrm{C} / \mathrm{min}$ heating rate. If no postcuring was detected, the conversion was considered as complete.

\subsubsection{Parallel plate rheometry}

Gel time was determined by parallel plate rheometry using AR2000 device from TA Instruments (New Castle, DE, USA) with $25 \mathrm{~mm}$ diameter plate and $200 \mu \mathrm{m}$ gap between the plates in oscillation mode. The test frequency was $10 \mathrm{~Hz}$, the applied temperature was $100^{\circ} \mathrm{C}$. The gel time was determined from the intersection of the recorded shear storage $\left(G^{\prime}\right)$ and shear loss $\left(G^{\prime \prime}\right)$ modulus values.

\subsubsection{Dynamic mechanical analysis (DMA)}

For the investigations of the dynamic mechanical properties and for the determination of the $T_{\mathrm{g}}$ values 
DMA tests were carried out in three point bending setup with TA Q800 device of TA Instruments (New Castle, DE, USA). The temperature range was $25-$ $225^{\circ} \mathrm{C}$ with $3^{\circ} \mathrm{C} / \mathrm{min}$ heat rate. The frequency was $1 \mathrm{~Hz}$. The size of the specimens was $50 \times 10 \times 2 \mathrm{~mm}$ (length $\times$ width $\times$ thickness), and the support span was $50 \mathrm{~mm}$. The amplitude was strain controlled with $0.1 \%$ relative strain.

\subsubsection{Tensile test}

To determine the epoxy systems tensile strength and Young's modulus a Zwick Z005 (Ulm, Germany) type computer controlled universal tester was used with a $5 \mathrm{kN}$ load cell. The specimen dimensions were $100 \times 10 \times 2 \mathrm{~mm}$ (length $\times$ width $\times$ thickness) according to EN ISO 527-3. The initial test length was $100 \mathrm{~mm}$. The test speed was $2 \mathrm{~mm} / \mathrm{min}$. The temperature was $22^{\circ} \mathrm{C}$ and the relative humidity was $58.3 \%$.

\subsubsection{Bending test}

To determine the bending strength and bending modulus values of the epoxy systems three point bending tests were carried out according to EN ISO 178 with a Zwick Z005 (Ulm, Germany) type computer controlled universal tester with $5 \mathrm{kN}$ load cell. The specimen size was $40 \times 25 \times 2 \mathrm{~mm}$ (length $\times$ width $\times$ thickness), and the support span was $32 \mathrm{~mm}$. The test speed was $2 \mathrm{~mm} / \mathrm{min}$. The temperature was $22^{\circ} \mathrm{C}$ and the relative humidity was $58.3 \%$.

\subsubsection{Hardness}

To investigate the hardness of the various epoxy systems with anhydride and amine type curing agents Shore-D type hardness was determined with Zwick (Ulm, Germany) H04.3150 hardness tester.

\subsubsection{Thermogravimetrical analysis (TGA)}

The TGA measurements were carried out with a Setaram Labsys (Caluire, France) type TGA device. The heating range was $30-700^{\circ} \mathrm{C}$ with $10^{\circ} \mathrm{C} / \mathrm{min}$ heating rate in nitrogen atmosphere. Setaram type $400 \mu \mathrm{L}$ aluminium oxide pan was used. The sample size was $15-20 \mathrm{mg}$. From the recorded TG data dTG values were calculated by Setaram Setsys software.

\section{Results and discussion \\ 3.1. Curing behaviour}

To study the curing behaviour of the novel glucosebased epoxy resin components and compare them to the mineral oil based ones, DSC measurements were carried out. Figure 2 shows the first DSC heating cycle of the EP systems with amine (DETDA) and anhydride (AR917) type curing agents and Table 2 summarizes the DSC results.

According to Figure 2 and Table 2, both novel glucose-based resins could be successfully cured both with amine and anhydride type curing agents. In case of AR917 no significant difference could be noticed between the heat flow profile of the different EPs, the curing occurred in rather narrow temperature zone, with a peak temperature around $130^{\circ} \mathrm{C}$. The curing process was significantly slower in the case of DETDA and the EP systems needed higher curing temperature than with AR917. The aliphatic
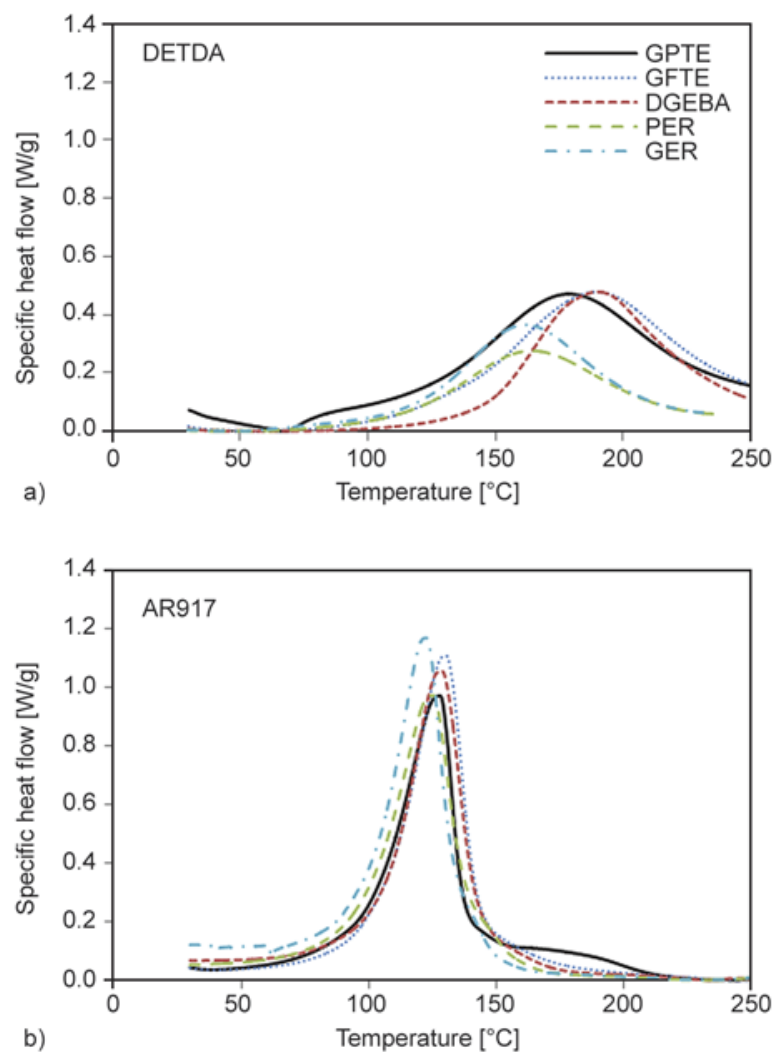

Figure 2. Curing process of the EP systems with DETDA (a) and AR917 (b) curing agents (first DSC cycle)

Table 2. DSC results of the EP systems with DETDA and AR917 curing agents

\begin{tabular}{|l|c|c|c|c|c|c|c|c|c|c|}
\hline \multicolumn{1}{|c|}{ Base resin } & \multicolumn{2}{c|}{ GPTE } & \multicolumn{2}{c|}{ GFTE } & \multicolumn{2}{c|}{ DGEBA } & \multicolumn{2}{c|}{ PER } & \multicolumn{2}{c|}{ GER } \\
\hline \multicolumn{1}{|c|}{ Curing agent } & DETDA & AR917 & DETDA & AR917 & DETDA & AR917 & DETDA & AR917 & DETDA & AR917 \\
\hline Total specific reaction enthalpy $[\mathrm{J} / \mathrm{g}]$ & 365.9 & 396.3 & 332.6 & 414.5 & 295.6 & 380.6 & 327.9 & 388.1 & 418.7 & 371.7 \\
\hline Peak $\left[{ }^{\circ} \mathrm{C}\right]$ & 179 & 133 & 190 & 130 & 190 & 129 & 164 & 125 & 162 & 123 \\
\hline$T_{\mathrm{g}}\left[{ }^{\circ} \mathrm{C}\right]$ & 210 & 178 & 173 & 157 & 179 & 155 & 98 & 116 & 76 & 99 \\
\hline
\end{tabular}


resins cured at lower temperature, while the heat flow curve of the aromatic DGEBA and cycloaliphatic glucose-based resins was shifted to higher temperatures.

As for the $T_{\mathrm{g}}$ values, according to Table 2, the aromatic and glucose-based systems had higher $T_{\mathrm{g}}$ with the aromatic amine type DETDA than with anhydride type AR917 curing agent, while the aliphatic ones had lower $T_{\mathrm{g}}$ with DETDA. GPTE type glucosebased EP systems showed the highest $T_{\mathrm{g}}$ values among all investigated resins, followed by glucosebased cycloaliphatic GFTE and aromatic DGEBA, while the aliphatic ones had the lowest values, as expected.

\subsection{Gelling}

Prior to specimen moulding the gel time of the EP systems was determined as well. The applied temperature during the measurement was determined on the basis of DSC results: with DETDA a constant temperature of $175^{\circ} \mathrm{C}$, while with $\mathrm{AR} 917100^{\circ} \mathrm{C}$ was applied. Table 3 shows the gel times of the EP systems with DETDA (at $175^{\circ} \mathrm{C}$ ) and AR917 (at $100^{\circ} \mathrm{C}$ ). Table 3 shows that curing with amine type DETDA leads to shorter gel times than curing with the anhydride type AR917 in all EP systems. In case of AR917 the glucose-based EP systems had similar gel times than DGEBA, while with DETDA the glucose-based EP components have significantly lower gel times than the DGEBA. With both curing agents the aliphatic resins showed the highest reactivity. According to these results, the gel times of the novel

Table 3. Gel times of the EP systems with DETDA and AR917 curing agents

\begin{tabular}{|c|c|c|c|c|c|c|}
\hline \multicolumn{2}{|c|}{} & \multicolumn{5}{|c|}{ Base resin } \\
\hline \multirow{2}{*}{$\begin{array}{c}\text { Curing } \\
\text { agent }\end{array}$} & GPTE & GFTE & DGEBA & PER & GER \\
\hline \multirow{2}{*}{$\left.t_{\text {gel }[\mathrm{s}]}\right]$} & DETDA & 586 & 552 & 862 & 448 & 420 \\
\cline { 2 - 7 } & AR917 & 955 & 908 & 935 & 532 & 769 \\
\hline
\end{tabular}

glucose-based resins are appropriate for processing and can be well-adopted to the requirements of the common composite preparation method by choosing the type of the curing agent.

\subsection{Dynamic mechanical properties}

In order to compare the dynamic mechanical properties of the glucose-based EP systems compared to the mineral oil based ones, DMA measurements were carried out. The storage modulus and loss fac$\operatorname{tor}(\tan \delta)$ values in the function of temperature can be seen in Figure 3.

The storage moduli of the different EP systems were compared at $0,25,50$ and $75^{\circ} \mathrm{C}$. From the peak position of $\tan \delta$ curves in the function of temperature, $T_{\mathrm{g}}$ values of the EP systems were determined. Table 4 shows the storage modulus at $0,25,50$ and $75^{\circ} \mathrm{C}$ and compares the $T_{\mathrm{g}}$ values determined by DSC and DMA.

According to Table 4 there was no significant difference between the storage modulus values of the EP systems below the $T_{\mathrm{g}}$. The storage modulus of the novel glucose-based resins at lower temperatures is higher than the values of DGEBA, and above $50^{\circ} \mathrm{C}$ it still in the same region of the storage modulus of DGEBA. In the case of PER and GER $75^{\circ} \mathrm{C}$ is close to the $T_{\mathrm{g}}$ of these aliphatic systems, which explains the low storage modulus values at this temperature. The $T_{\mathrm{g}}$ values determined by DMA showed similar tendency than the ones determined by DSC: the glucose-based aliphatic GPTE had much higher $T_{\mathrm{g}}$ than DGEBA both with amine type DETDA and anhydride type AR917, while the $T_{\mathrm{g}}$ values of GFTE were in the same range as DGEBA.

\subsection{Mechanical properties}

In order to compare mechanical properties and hardness of the glucose-based EP resins to the mineral oil based ones, tensile, bending and Shore-D type

Table 4. Storage modulus measured by DMA and $T_{\mathrm{g}}$ values determined by DSC and DMA in EP systems cured with DETDA and AR917 curing agents

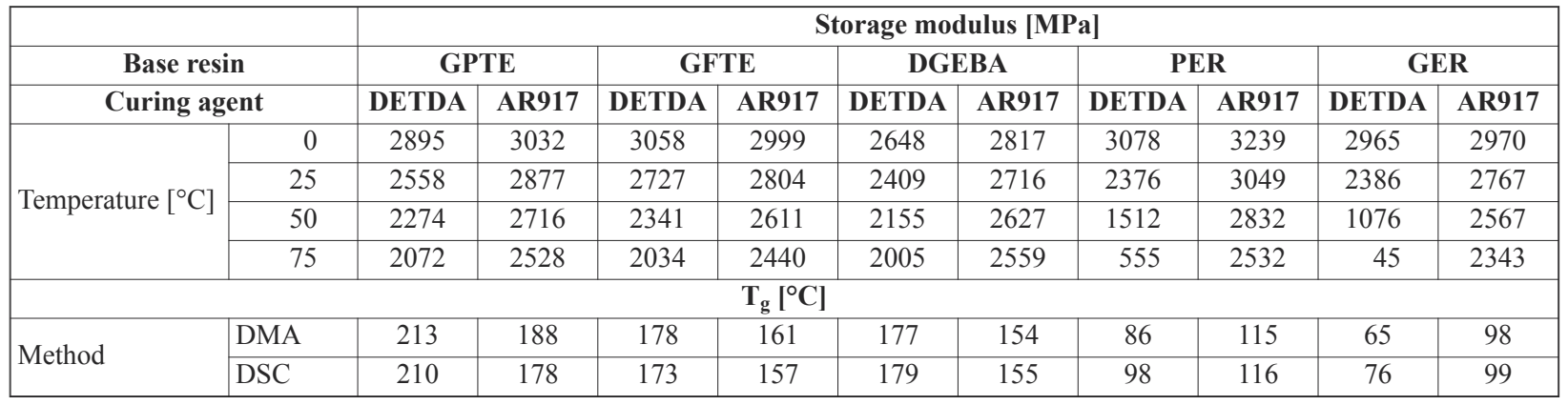



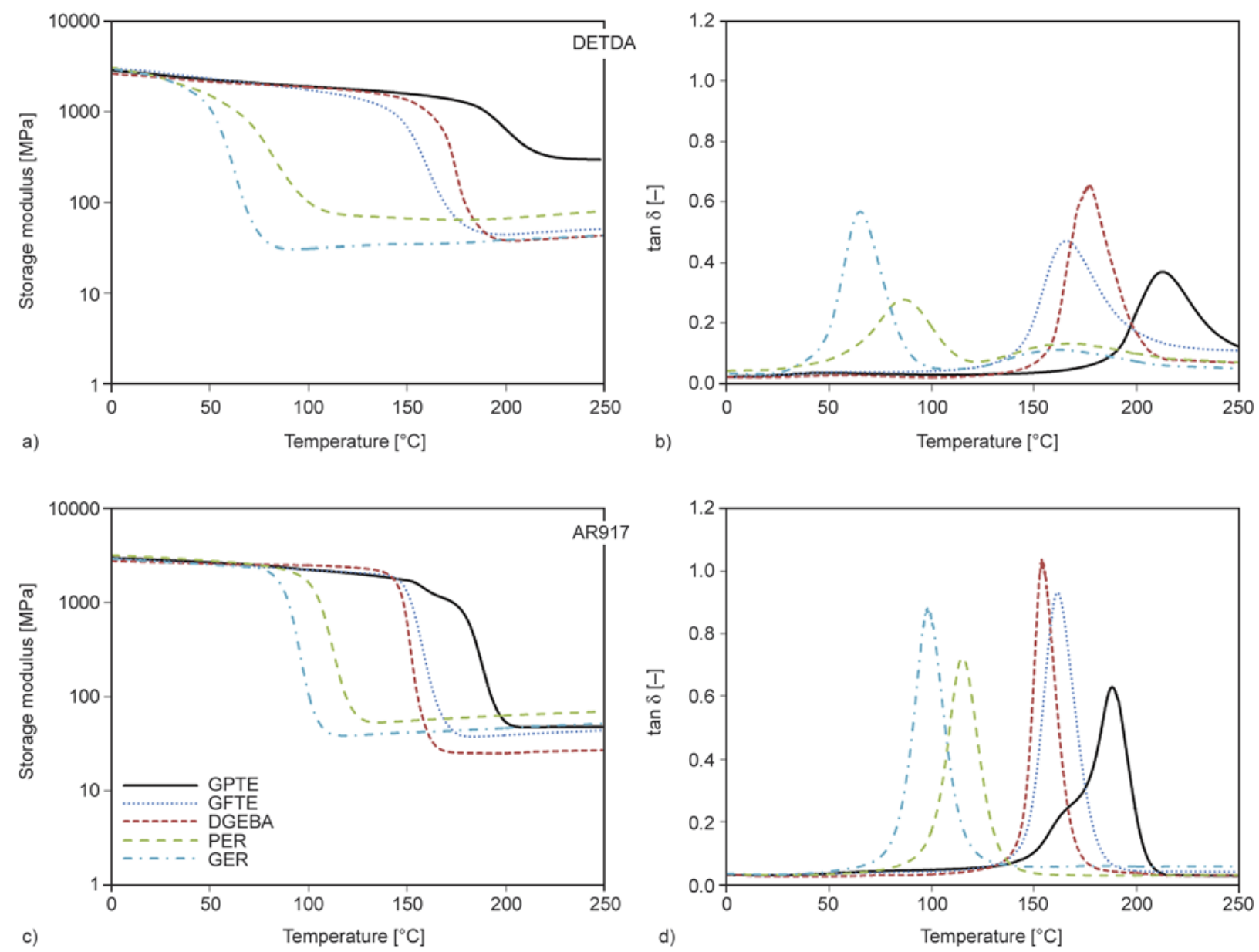

Figure 3. Storage modulus and $\tan \delta$ curves of EP systems with DETDA (a, b) and AR917 (c, d) curing agents

hardness tests were carried out. From the measured force and crosshead travel values, tensile strength and Young's modulus, bending strength and bending modulus were determined (Table 5).

Based on the results showed in Table 5, DGEBA has the highest tensile strength both with DETDA and AR917 curing agent. Noteworthy worsening in the tensile strength was detected in the case of the glucose-based EP components (GPTE, GFTE) com- pared to the mineral oil based ones. All EP systems have lower tensile strength with amine type DETDA than with anhydride type AR917, which may be explained with the high temperature heat treatment $\left(2 \mathrm{~h}\right.$ at $\left.175^{\circ} \mathrm{C}\right)$ necessary for proper conversion, probably causing already degradation in the crosslinked resin. Despite the tendency in tensile strength values, the GPTE and GFTE with AR917 have almost the highest Young's modulus value. Similar trend

Table 5. Comparison of the mechanical properties and hardness of glucose-based EP resins to mineral oil based ones with DETDA and AR917 curing agents

\begin{tabular}{|c|c|c|c|c|c|c|c|c|c|c|c|}
\hline \multirow{2}{*}{\multicolumn{2}{|c|}{$\begin{array}{c}\text { Base resin } \\
\text { Curing agent }\end{array}$}} & \multicolumn{2}{|c|}{ GPTE } & \multicolumn{2}{|c|}{ GFTE } & \multicolumn{2}{|c|}{ DGEBA } & \multicolumn{2}{|c|}{ PER } & \multicolumn{2}{|c|}{ GER } \\
\hline & & DETDA & AR917 & DETDA & AR917 & DETDA & AR917 & DETDA & AR917 & DETDA & AR917 \\
\hline \multirow{2}{*}{$\begin{array}{l}\text { Tensile strength } \\
{[\mathrm{MPa}]}\end{array}$} & Average value & 14.67 & 24.90 & 29.02 & 37.58 & 44.80 & 77.61 & 34.88 & 64.69 & 46.81 & 66.92 \\
\hline & Standard deviati & 4.01 & 4.08 & 8.75 & 9.13 & 14.18 & 0.79 & 9.97 & 0.78 & 0.32 & 0.34 \\
\hline \multirow{2}{*}{$\begin{array}{l}\text { Young's modulus } \\
\text { [GPa] }\end{array}$} & Averas & 2.23 & 2.50 & 2.48 & 2.66 & 2.26 & 2.54 & 2.27 & 2.66 & 2.33 & 2.66 \\
\hline & Standa & 0.06 & 0.07 & 0.05 & 0.11 & 0.07 & 0.04 & 0.02 & 0.05 & 0.04 & 0.07 \\
\hline \multirow{2}{*}{$\begin{array}{l}\text { Bending strength } \\
{[\mathrm{MPa}]}\end{array}$} & Average value & 49.11 & 86.86 & 62.84 & 68.86 & 86.84 & 94.87 & 85.85 & 91.67 & 85.81 & 94.41 \\
\hline & Standard deviati & 10.07 & 25.82 & 8.02 & 5.71 & 1.39 & 0.77 & 0.59 & 0.52 & 1.79 & 0.21 \\
\hline \multirow{2}{*}{$\begin{array}{l}\text { Bending modulus } \\
\text { [GPa] }\end{array}$} & Average value & 2.29 & 2.61 & 2.31 & 2.51 & 2.12 & 2.88 & 2.50 & 3.12 & 2.30 & 3.01 \\
\hline & Standard deviat & 0.12 & 0.12 & 0.47 & 0.16 & 0.10 & 0.03 & 0.01 & 0.02 & 0.28 & 0.02 \\
\hline \multirow{2}{*}{$\begin{array}{l}\text { Hardness } \\
\text { [Shore-D] }\end{array}$} & Average value & 105.72 & 107.82 & 107.28 & 109.06 & 103.98 & 106.20 & 99.64 & 107.12 & 99.32 & 105.84 \\
\hline & Standard deviation & 2.52 & 1.94 & 1.59 & 1.05 & 1.93 & 0.57 & 2.18 & 0.53 & 2.05 & 0.65 \\
\hline
\end{tabular}


can be seen in the case of the bending properties. The bending strength of the glucose-based EP systems is lower than the synthetic resins except the GPTE with AR917. The bending modulus values are the lowest in the case of the glucose-based epoxy components with DETDA. Basically the glucose-based and the mineral oil based epoxy components' modulus values are comparable with each other using the same curing agent.

According to the hardness tests, the glucose-based epoxy components have the highest hardness among all the five examined EP components with both curing.

\subsection{Thermal behaviour}

Thermal stability of the synthesized bio-based epoxy resins, GPTE and GFTE was compared to the sta- bility of the applied aliphatic and aromatic synthetic resins (DGEBA, PER, GER) both in case of anhydride (AR917) and aromatic amine type hardener (DETDA). Figure 4 shows the TG and dTG curves of all epoxy resin systems with DETDA and AR917 curing agents.

Table 6 shows the temperature at 5 and 50 mass $\%$ loss $\left(T_{5 \text { mass } \%} ; T_{50 \text { mass } \%}\right)$, the maximum mass loss rate $\left(d T G_{\max }\right)$, the temperature belonging to this value $\left(T_{\mathrm{dTG} \max }\right)$ and the char yield at the end of the TGA test (at $700^{\circ} \mathrm{C}$ ).

Based on these results, the aromatic DGEBA had the highest thermal stability, the stability of the synthesized GPTE and GFTE is between the aliphatic resins and DGEBA. In the case of the glucosebased resins, the char yield values are significantly
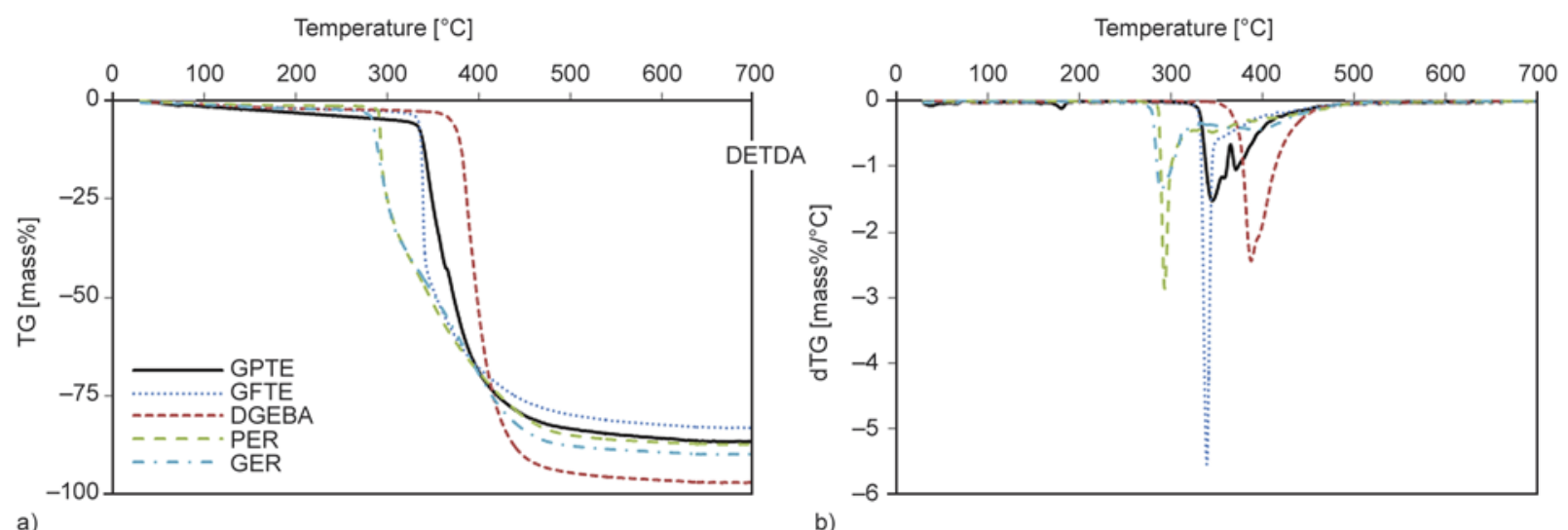

Temperature $\left[{ }^{\circ} \mathrm{C}\right]$

Temperature $\left[{ }^{\circ} \mathrm{C}\right]$

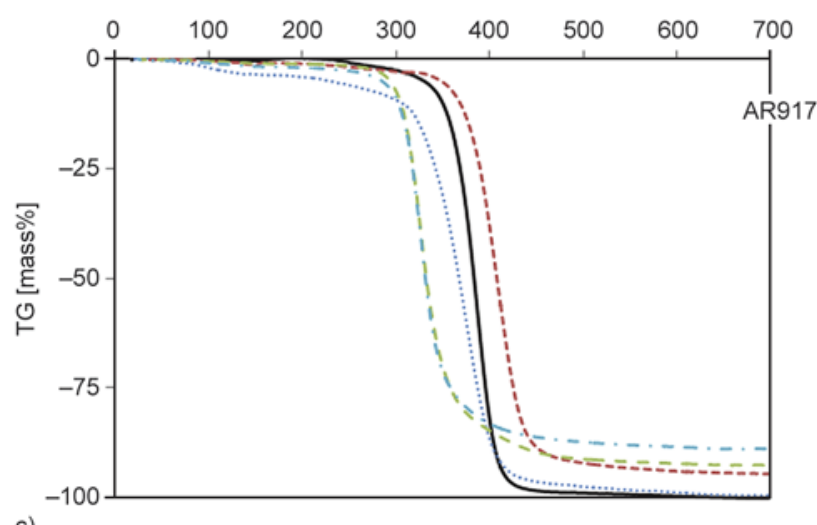

c)

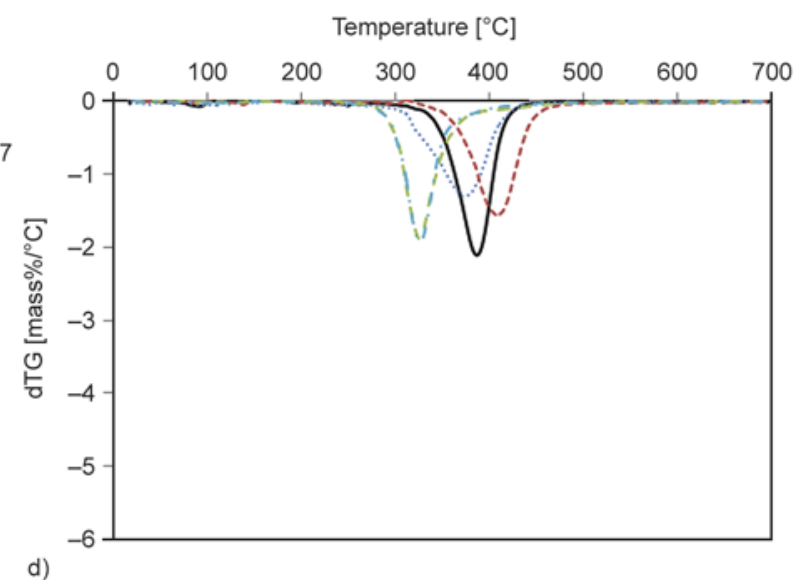

Figure 4. TG and dTG curves in function of temperature of the EP components with DETDA (a, b) and AR917 (c, d) curing agents

Table 6. $T_{5 \text { mass } \%} ; T_{50 \text { mass } \%} ; d T G_{\max } ; T_{\mathrm{dTG} \max }$ and char yield values of the EP systems with DETDA and AR917 curing agents

\begin{tabular}{|c|c|c|c|c|c|c|c|c|c|c|}
\hline Base resin & \multicolumn{2}{|c|}{ GPTE } & \multicolumn{2}{|c|}{ GFTE } & \multicolumn{2}{|c|}{ DGEBA } & \multicolumn{2}{|c|}{ PER } & \multicolumn{2}{|c|}{ GER } \\
\hline Curing agent & DETDA & AR917 & DETDA & AR917 & DETDA & AR917 & DETDA & AR917 & DETDA & AR917 \\
\hline$T_{5 \operatorname{mass} \%}\left[{ }^{\circ} \mathrm{C}\right]$ & 314 & 330 & 334 & 229 & 370 & 348 & 291 & 294 & 284 & 285 \\
\hline$T_{50 \text { mass } \%}\left[{ }^{\circ} \mathrm{C}\right]$ & 373 & 384 & 354 & 367 & 398 & 408 & 347 & 333 & 353 & 331 \\
\hline$d T G_{\max }\left[\mathrm{mass} \% /{ }^{\circ} \mathrm{C}\right]$ & -1.52 & -2.11 & -5.55 & -1.31 & -2.44 & -1.56 & -2.87 & -1.88 & -1.36 & -1.92 \\
\hline$T_{\mathrm{dTG} \max }\left[{ }^{\circ} \mathrm{C}\right]$ & 345 & 387 & 339 & 374 & 387 & 409 & 293 & 325 & 289 & 327 \\
\hline Char yield [mass\%] & 13.35 & 0.21 & 16.83 & 0.54 & 2.89 & 10.29 & 12.64 & 15.94 & 10.11 & 15.76 \\
\hline
\end{tabular}


higher with DETDA than with AR917, which may be explained by the high amount of ether type linkages derived from hydroxyl groups, which leads to the formation of an intumescent system when amine type hardeners are used [38].

\section{Conclusions}

Curing and rheological behaviour, glass transition temperature, mechanical and thermal properties of two novel glucose-based (GPTE, GFTE) EP components were investigated. The results were compared to the conventional, widely investigated aromatic DGEBA EP resin and as well as to GER and PER aliphatic EP resins, which are currently synthesized on mineral oil basis, but can be potentially produced from renewable sources.

According to the DSC results, the novel glucosebased resins could be successfully cured both with amine and anhydride type curing agents. In all investigated EPs the curing process was significantly slower and therefore higher curing temperatures were necessary with amine type hardener. As for the $T_{\mathrm{g}}$ values, GPTE type glucose-based EP systems showed the highest $T_{\mathrm{g}}$ values among all investigated resins, followed by glucose-based cycloaliphatic GFTE and aromatic DGEBA, while the aliphatic ones had the lowest values, as expected. As for the gelling properties, the glucose-based EPs had similar gel times with anhydride curing agent as DGEBA, while with amine hardener their gel time was significantly lower than in case of DGEBA. According to the DMA test results there was no significant difference between the storage modulus values of the EP systems below the $T_{\mathrm{g}}$. The storage modulus of the novel glucose-based resins is higher or above $50^{\circ} \mathrm{C}$ it is in the same region as the storage modulus of DGEBA. The $T_{\mathrm{g}}$ values determined by DMA showed similar tendency than the values determined by DSC.

According to the mechanical test results, the glucose based EP systems have lower tensile and bending strength, but the tensile modulus values are not significantly different from the synthetic EPs.

Based on the TGA measurements, the stability of the synthesized GPTE and GFTE is between the aliphatic resins and DGEBA. In the case of the glucose-based resins, the char yield values are significantly higher with DETDA than with AR917, which may be explained by the high amount of ether type linkages derived from hydroxyl groups, which leads to the formation of an intumescent system when amine type hardeners are used.

Based on the results, the newly synthesized glucopyranoside- and glucofuranoside-based renewable EP components are promising candidates to replace the commodity mineral oil based ones. Their major advantages are the high $T_{\mathrm{g}}$ (in some cases above $200^{\circ} \mathrm{C}$ ), adjustable gel time by choosing appropriate curing agent, high storage modulus values and hardness. In applications where bending stresses are dominant over the tensile ones, and outstanding $T_{\mathrm{g}}$ is required, these sugar-based resins offer a feasible renewable choice.

\section{Acknowledgements}

The research leading to these results has received funding from the European Union's Seventh Framework Programme (FP7/2007-2013) for the Clean Sky Joint Technology Initiative under grant agreement no 298090 (Topic manager: Dassault Aviation).

This work is connected to the scientific program of the 'Development of quality-oriented and harmonized $\mathrm{R}+\mathrm{D}+\mathrm{I}$ strategy and functional model at BME' and 'Talent care and cultivation in the scientific workshops of BME' project. This project is supported by New Széchenyi Plan (Project ID: TÁMOP-4.2.1/B-09/1/KMR-2010-0002), by NFÜ EU_ BONUS_12-1-2012-0026, by TÁMOP - 4.2.2.B-10/1;20100009. Andrea Toldy acknowledges the financial support received through János Bolyai Scholarship of the Hungarian Academy of Science.

\section{References}

[1] Koike T.: Progress in development of epoxy resin systems based on wood biomass in Japan. Polymer Engineering and Science, 52, 701-717 (2012). DOI: $10.1002 /$ pen.23119

[2] Huijbrechts A. A. M. L., Huang J., Schols H. A., van Langen B., Visser G. M., Boeriu C. G., Sudhölter E. J. R.: 1-Allyloxy-2-hydroxy-propyl-starch: Synthesis and characterization. Journal of Polymer Science Part A: Polymer Chemistry, 45, 2734-2744 (2007). DOI: $10.1002 /$ pola.22029

[3] Huijbrechts A. M. L., ter Haar R., Schols H. A., Franssen M. C. R., Boeriu C. G., Sudhölter E. J. R.: Synthesis and application of epoxy starch derivatives. Carbohydrate Polymers, 79, 858-866 (2010). DOI: $10.1016 /$ j.carbpol.2009.10.012

[4] Liu X. Q., Huang W., Jiang Y. H., Zhu J., Zhang C. Z.: Preparation of a bio-based epoxy with comparable properties to those of petroleum-based counterparts. Express Polymer Letters, 6, 293-298 (2012). DOI: $10.3144 /$ expresspolymlett.2012.32 
[5] Sarwono A., Man Z., Bustam M. A.: Blending of epoxidised palm oil with epoxy resin: The effect on morphology, thermal and mechanical properties. Journal of Polymers and the Environment, 20, 540-549 (2012). DOI: 10.1007/s10924-012-0418-5

[6] Güner F. S., Yağc i Y., Erciyes A. T.: Polymers from triglyceride oils. Progress in Polymer Science, 31, 633670 (2006).

DOI: 10.1016/j.progpolymsci.2006.07.001

[7] Tan S. G., Chow W. S.: Biobased epoxidized vegetable oils and its greener epoxy blends: A review. PolymerPlastics Technology and Engineering, 49, 1581-1590 (2010).

DOI: $10.1080 / 03602559.2010 .512338$

[8] Wang R., Schuman T. P.: Vegetable oil-derived epoxy monomers and polymer blends: A comparative study with review. Express Polymer Letters, 7, 272-292 (2013).

DOI: $10.3144 /$ expresspolymlett.2013.25

[9] Khot S. N., Lascala J. J., Can E., Morye S. S., Williams G. I., Palmese G. R., Kusefoglu S. H., Wool R. P.: Development and application of triglyceride-based polymers and composites. Journal of Applied Polymer Science, 82, 703-723 (2001).

DOI: $10.1002 /$ app. 1897

[10] Can E., Küsefoğlu S., Wool R. P.: Rigid thermosetting liquid molding resins from renewable resources. II. Copolymers of soybean oil monoglyceride maleates with neopentyl glycol and bisphenol A maleates. Journal of Applied Polymer Science, 83, 972-980 (2002). DOI: $10.1002 /$ app.2277

[11] Guenter S., Rieth R., Rowbotton K. T.: Ullmann's encyclopedia of industrial chemistry, $6^{\text {th }}$ edition. Wiley, New York (2003).

[12] Ratna D.: Mechanical properties and morphology of epoxidized soyabean-oil-modified epoxy resin. Polymer International, 50, 179-184 (2001).

DOI: $10.1002 / 1097-0126(200102) 50: 2<179::$ AIDPI603>3.0.CO;2-E

[13] Zhu J., Chandrashekhara K., Flanigan V., Kapila S.: Curing and mechanical characterization of a soy-based epoxy resin system. Journal of Applied Polymer Science, 91, 3513-3518 (2004).

DOI: $10.1002 /$ app.13571

[14] Earls J. D., White J. E., López L. C., Lysenko Z., Dettloff M. L., Null M. J.: Amine-cured $\omega$-epoxy fatty acid triglycerides: Fundamental structure-property relationships. Polymer, 48, 712-719 (2007).

DOI: 10.1016/j.polymer.2006.11.060

[15] Li J., Du Z., Li H., Zhang C.: Porous epoxy monolith prepared via chemically induced phase separation. Polymer, 50, 1526-1532 (2009).

DOI: 10.1016/j.polymer.2009.01.049

[16] Mustata F., Tudorachi N., Rosu D.: Curing and thermal behavior of resin matrix for composites based on epoxidized soybean oil/diglycidyl ether of bisphenol A. Composites Part B: Engineering, 42, 1803-1812 (2011). DOI: $10.1016 /$ j.compositesb.2011.07.003
[17] Park S-J., Jin F-L., Lee J-R.: Thermal and mechanical properties of tetrafunctional epoxy resin toughened with epoxidized soybean oil. Materials Science and Engineering A, 374, 109-114 (2004).

DOI: $10.1016 /$ j.msea.2004.01.002

[18] Park S-J., Jin F-L., Lee J-R.: Effect of biodegradable epoxidized castor oil on physicochemical and mechanical properties of epoxy resins. Macromolecular Chemistry and Physics, 205, 2048-2054 (2004).

DOI: $10.1002 / \mathrm{macp} .200400214$

[19] Gerbase A. E., Petzhold C. L., Costa A. P. O.: Dynamic mechanical and thermal behavior of epoxy resins based on soybean oil. Journal of the American Oil Chemists' Society, 79, 797-802 (2002).

DOI: $10.1007 / \mathrm{s} 11746-002-0561-\mathrm{z}$

[20] Miyagawa H., Misra M., Drzal L. T., Mohanty A. K.: Fracture toughness and impact strength of anhydridecured biobased epoxy. Polymer Engineering and Science, 45, 487-495 (2005).

DOI: $10.1002 /$ pen.20290

[21] Altuna F. I., Espósito L. H., Ruseckaite R. A., Stefani P. M.: Thermal and mechanical properties of anhydride-cured epoxy resins with different contents of biobased epoxidized soybean oil. Journal of Applied Polymer Science, 120, 789-798 (2011).

DOI: $10.1002 / a p p .33097$

[22] Gupta A. P., Ahmad S., Dev A.: Modification of novel bio-based resin-epoxidized soybean oil by conventional epoxy resin. Polymer Engineering and Science, 51, 1087-1091 (2011). DOI: $10.1002 /$ pen.21791

[23] Karger-Kocsis J., Grishchuk S., Sorochynska L., Rong M. Z.: Curing, gelling, thermomechanical, and thermal decomposition behaviors of anhydride-cured epoxy (DGEBA)/epoxidized soybean oil compositions. Polymer Engineering and Science, 54, 747-755 (2013). DOI: 10.1002/pen.23605

[24] Kim J. R., Sharma S.: The development and comparison of bio-thermoset plastics from epoxidized plant oils. Industrial Crops and Products, 36, 485-499 (2012). DOI: $10.1016 /$ j.indcrop.2011.10.036

[25] Jin F-L., Park S-J.: Thermal and rheological properties of vegetable oil-based epoxy resins cured with thermally latent initiator. Journal of Industrial and Engineering Chemistry, 13, 808-814 (2007).

[26] Niedermann P., Szebényi G., Toldy A.: Effect of epoxidized soybean oil on curing, rheological, mechanical and thermal properties of aromatic and aliphatic epoxy resins. Journal of Polymers and the Environment, in press (2014). DOI: $10.1007 / \mathrm{s} 10924-014-0673-8$

[27] Devi A., Srivastava D.: Studies on the blends of cardanol-based epoxidized novolac resin and CTPB. European Polymer Journal, 43, 2422-2432 (2007). DOI: 10.1016/j.eurpolymj.2007.03.006 
[28] Yadav R., Awasthi P., Srivastava D.: Studies on synthesis of modified epoxidized novolac resin from renewable resource material for application in surface coating. Journal of Applied Polymer Science, 114, 1471-1484 (2009).

DOI: 10.1002/app.30581

[29] Yadav R., Srivastava D.: Studies of cardanol-based epoxidized novolac resin and its blends. Chemistry and Chemical Technology, 2, 173-184 (2008).

[30] Pan X., Sengupta P., Webster D. C.: High biobased content epoxy-anhydride thermosets from epoxidized sucrose esters of fatty acids. Biomacromolecules, 12, 2416-2428 (2011).

DOI: $10.1021 / \mathrm{bm} 200549 \mathrm{c}$

[31] Sachinvala N. D., Winsor D. L., Menescal R. K., Ganjian I., Niemczura W. P., Litt M. H.: Sucrose-based epoxy monomers and their reactions with diethylenetriamine. Journal of Polymer Science Part A: Polymer Chemistry, 36, 2397-2413 (1998).

DOI: 10.1002/(SICI)1099-0518(19980930)36:13<2397

$$
\because \text { AID-POLA27>3.0.CO;2-4 }
$$

[32] Shibata M., Nakai K.: Preparation and properties of biocomposites composed of bio-based epoxy resin, tannic acid, and microfibrillated cellulose. Journal of Polymer Science Part B: Polymer Physics, 48, 425-433 (2010).

DOI: $10.1002 /$ polb.21903
[33] Feng X., East A. J., Hammond W. B., Zhang Y., Jaffe M.: Overview of advances in sugar-based polymers. Polymers for Advanced Technologies, 22, 139-150 (2011). DOI: $10.1002 /$ pat.1859

[34] Fenoulliot F., Rousseau A., Colomines G., Saint-Loup R., Pascault J-P.: Polymers from renewable 1,4:3,6dianhydrohexitols (isosorbide, isomannide and isoidide): A review. Progress in Polymer Science, 35, 578622 (2010).

DOI: 10.1016/j.progpolymsci.2009.10.001

[35] Lukaszczyk J., Janicki B., Kaczmarek M.: Synthesis and properties of isosorbide based epoxy resin. European Polymer Journal, 47, 1601-1606 (2011).

DOI: $10.1016 /$ j.eurpolymj.2011.05.009

[36] Chrysanthos M., Galy J., Pascault J-P.: Preparation and properties of bio-based epoxy networks derived from isosorbide diglycidyl ether. Polymer, 52, 36113620 (2011).

DOI: 10.1016/j.polymer.2011.06.001

[37] Rapi Zs., Bakó P., Keglevich Gy., Bodzay B., Szolnoki B., Niedermann P., Toldy A., Marosi Gy.: Synthesis and characterization of bio-based epoxy resin components derived from D-glucose. European Polymer Journal, in press (2014).

DOI: $10.1016 /$ j.eurpolymj.2014.09.025

[38] Le Bras M., Camino G., Bourbigot S., Delobel R.: Fire retardancy of polymers: The use of intumescence. The Royal Chemical Society, Cambridge (1998). 